\title{
Analysis of Several Problems in the Construction of Sponge City
}

\author{
Wei Li ${ }^{*}$ \\ China Merchants Chongqing Communications Technology Research \& Design Institute Co., Ltd., China \\ *Corresponding author: Wei Li, 271733704@qq.com
}

Copyright: (C) 2022 Author(s). This is an open-access article distributed under the terms of the Creative Commons Attribution License (CC BY 4.0), permitting distribution and reproduction in any medium, provided the original work is cited.

\begin{abstract}
Sponge city refers to a new urban construction concept used to solve urban flood disasters and water ecological problems. It is important for the construction of ecological civilization. It plays an important role in the green development and livability of the city. In the construction of a sponge city, it is necessary to make special urban planning and improve the top-level design. In recent years, China has developed a number of sponge city pilot projects. The numerous experiments act as important references for the urban construction in China. This paper mainly analyzes the requirements for the construction of sponge city and discusses several problems as well as solutions in the construction.
\end{abstract}

Keywords: Sponge city; Construction problems; Solution strategies

Online publication: January 12, 2022

\section{Introduction}

The construction of sponge city plays an important role in urban water conservation and flood disaster prevention in China. It is an important way to solve urban water ecological problems. The construction of sponge city is conducive to reducing the impact on the ecological environment in urban construction and development as well as promoting a green, innovative, and coordinated development of the city. It is also an important channel for the construction of social ecological civilization in China. In recent years, China has developed a number of pilot projects and made some achievements from them. With these pilot projects, several problems in the construction of sponge city have surfaced. The analysis of these problems is conducive to the construction and development of sponge city.

\section{Key points in the planning and construction of sponge cities}

From 2015 to 2016, the list of sponge cities in China has been published. There are two batches of sponge cities. Thirty cities have been selected as pilot units for the construction, with an investment of more than 400 billion yuan ${ }^{[1]}$. The development of these pilot sponge cities provides an effective reference for the construction of sponge cities in China and a reproducible construction template for the construction of other sponge cities. Through the construction of the first and second batch of pilot sponge cities, it can be concluded that the construction of sponge cities plays an important role in the improvement of urban hydrological environment as well as the prevention and treatment of flood and waterlogging disasters, affirming the feasibility of the construction of sponge cities in China, and highlighting the problems that need to be paid attention to in the construction of sponge cities, which play important roles in the construction of sponge cities and the promotion of sponge cities in China (Table 1 and Table 2). 
Table 1. First batch of sponge cities in China

\begin{tabular}{cc}
\hline City & Annual river runoff control \\
\hline Baicheng & $70 \%$ to $85 \%$ \\
Qian'an & $75 \%$ to $85 \%$ \\
Jinan & $75 \%$ to $85 \%$ \\
Hebi & $80 \%$ to $85 \%$ \\
Xixian New Area & $70 \%$ to $85 \%$ \\
Zhenjiang & $70 \%$ to $85 \%$ \\
Pingxiang & $70 \%$ to $85 \%$ \\
Chizhou & $80 \%$ to $85 \%$ \\
Wuhan & $80 \%$ to $85 \%$ \\
Changde & $70 \%$ to $85 \%$ \\
Chongqing & $70 \%$ to $85 \%$ \\
Suining & $70 \%$ to $85 \%$ \\
\hline
\end{tabular}

Table 2. Second batch of sponge cities in China

\begin{tabular}{cc}
\hline City & Annual river runoff control \\
\hline Beijing & $70 \%$ to $85 \%$ \\
Tianjin & $70 \%$ to $85 \%$ \\
Dalian & $80 \%$ to $85 \%$ \\
Qingdao & $80 \%$ to $85 \%$ \\
Xining & $60 \%$ to $85 \%$ \\
Guyuan & $60 \%$ to $85 \%$ \\
Qingyang & $70 \%$ to $85 \%$ \\
Yuxi & $70 \%$ to $85 \%$ \\
Shanghai & $75 \%$ to $85 \%$ \\
Ningbo & $75 \%$ to $85 \%$ \\
Fuzhou & $75 \%$ to $85 \%$ \\
Shenzhen & $85 \%$ to $90 \%$ \\
Zhuhai & $85 \%$ to $90 \%$ \\
Sanya & $85 \%$ to $90 \%$ \\
\hline
\end{tabular}

\subsection{Formulating scientific urban planning}

According to the relevant regulations on sponge city planning issued by the Ministry of Housing and UrbanRural Development, it is necessary to clarify diversified contents, such as condition assessment, construction objectives, construction ideas, and control requirements, before the construction. It is not only necessary to have macro-overall planning, but also specific qualitative and quantitative data analysis to promote the implementation of various control indicators ${ }^{[2]}$.

\subsection{Playing an exemplary and guiding role}

In the construction of sponge city, it is necessary to perform well in project demonstration and promotion as well as strictly implement institutionalization, localization, and standardized application. For pilot areas, it is important to clarify the objectives and problem orientation, prepare scientific and systematic schemes as well as implementation plans, encourage design methods and technological innovation, improve the 
project quality, and publicize well. This would ensure the project quality and improve the satisfaction of the people ${ }^{[3]}$.

\subsection{Building a complete urban planning policy}

In order to promote the scientificity of sponge city planning, it is necessary to build a scientific, comprehensive, and long-term management and control mechanism. At present, the construction of sponge city is in the primary stage and the relevant legal system is still incomplete; in addition, the sustainable and long-term development concept, which is required to further improve the relevant laws and regulations as well as build city planning systems, has not been formed. It is necessary to build a diversified sponge city construction system, including project initiation, construction drawings, operation, and management, as well as integrate the construction and management of sponge city into the normal management of the city.

\section{Problems and countermeasures in the construction of sponge city}

The construction of sponge city in China is still in the primary construction stage. The construction ideas and methods are relatively backward, resulting in many problems in the construction of sponge city. There are many problems in policy construction, urban transformation, and rainwater runoff pollution control, which affect the improvement and continuous promotion of the construction. Therefore, it is necessary to analyze and investigate the problems in the construction of sponge city as well as work out corresponding countermeasures for them.

Table 3. Analysis of the problems in the construction of sponge city

\begin{tabular}{ll}
\hline \multicolumn{1}{c}{ Problem } & \multicolumn{1}{c}{ Countermeasures } \\
\hline $\begin{array}{l}\text { Imperfect policies and insufficient } \\
\text { standardization }\end{array}$ & $\begin{array}{l}\text { Formulate standardization programs, promote multisectoral cooperation, and strengthen } \\
\text { policy guidance from both macro and micro aspects. }\end{array}$ \\
& $\begin{array}{l}\text { Increase publicity and enhance people's support for urban transformation; improve } \\
\text { Difficult urban transformation }\end{array}$ \\
& $\begin{array}{l}\text { construction, strengthen construction management, improve management efficiency, and } \\
\text { strengthen cost control. }\end{array}$ \\
Rainwater runover pollution & Formulate rainwater runoff pollution targets and explore new technical forms. \\
\hline
\end{tabular}

\subsection{Imperfect policies and insufficient standardization}

The construction of sponge city in China is still in its infancy, lacking in technology and experience. It is difficult to formulate a scientific sponge city planning in a short time. Therefore, in order to ensure the scientificity of sponge city planning, there are many departments involved in the construction, including the cooperation of multiple departments, such as urban planning, garden construction, and water supply and drainage ${ }^{[4]}$. In the construction of sponge city, some urban areas only formulate preliminary guidance schemes from the macro perspective. However, due to the large pilot area and complex construction projects, it is impossible to effectively guide the planning projects. Although some cities have set up special plans for the construction of sponge city, they have not coordinated the development from the overall plan, resulting in contradictions and conflicts in the implementation; in addition, it is difficult for follow-up departments to coordinate and build.

In view of this condition, each sponge city needs to plan well from the macro and micro levels in consideration of the specific situation of the city. Firstly, the macro development strategy is formulated from the macro level in line with the national guidance requirements for the construction and the specific planning of the city. The specific plan for the construction is formulated through the exchange with foreign 
experts and the reference of relevant literatures ${ }^{[5]}$. Secondly, from the micro level, it is necessary to carry out the overall construction planning step by step in consideration of the specific characteristics of the city, formulate special construction guidance according to the operation requirements of each step, clarify the responsibilities of various departments, manage the division of labor well, give full play to the joint force of various departments, and improve the construction effect of sponge city.

\subsection{Difficulty in transformation}

The reconstruction of sponge city is based on traditional old urban areas. The infrastructure construction facilities such as water supply and drainage as well as greening and rainwater resources collection in the old urban area cannot meet the development needs of modern cities. In the construction of sponge city, pipe network reconstruction needs to be carried out again, in which it involves land acquisition, demolition, and other activities. The project scale is large, and the construction period is long, so there are many difficulties in the construction ${ }^{[6]}$. In addition, the degree of participation among the residents is low, so it is difficult to implement the comprehensive participation and supervision mechanism of the masses, resulting in many management loopholes.

The reconstruction of sponge city is difficult, which is a problem in all urban construction. Therefore, it is necessary to explore an effective model to provide large-scale replication for the reconstruction of sponge city. On this basis, reasonable solution strategies have been explored while taking into account of the specific situation of the city ${ }^{[7]}$. First, the publicity of sponge city should be strengthened to ensure that the residents realize the significance of the construction and its value to the long-term development of the city, promote their participation, win the support of the public, and ensure a smooth progress in the effort of land acquisition and demolition. Second, the construction period is long. In that way, sectional construction can be adopted. Different construction sections can be set according to the overall planning. The construction of the next section can be carried out after the construction of one section has been completed and has passed the inspection, which will not only reduce the pressure of project management, but also weaken the impact on the residents' lives ${ }^{[8]}$. In addition, the original pipeline shall be used as much as possible in the planning to reduce the construction burden and avoid material waste.

\subsection{Control of rainwater runover pollution}

The main problems to be solved in the construction of sponge city include urban waterlogging and rainwater runoff pollution. However, from the construction, most cities do not pay attention to urban runoff pollution and neglect the water treatment system ${ }^{[9]}$. As a result, the idea of pollution is not included in the construction of sponge city. Therefore, it is necessary to control rainwater runoff pollution in future development.

In the construction of sponge city, it is important to reasonably plan the objectives of rainwater runoff control, which can be carried out from four aspects: total runoff, runoff peak, runoff pollution, and resource utilization. From the review of foreign literatures, the total annual runoff of green land needs to be controlled between $80 \%$ and $85 \%$, but there are many factors affecting runoff discharge, including opening intensity, soil properties, vegetation coverage, and other factors. It is necessary to explore new technical forms as support and determine the final implementation scheme in consideration of the local economic situation ${ }^{[10]}$.

\section{Conclusion}

In conclusion, in the construction of sponge city, it is necessary to ensure the scientificity of urban planning, improve the top-level design of urban planning, promote the smooth development of sponge city planning 
in China, build macro and micro urban management systems as well as standardized sponge city construction standards, improve the construction effect of sponge city according to the specific situation of the city, solve various problems in the construction of sponge city, and improve China's water ecological environment.

\section{Disclosure statement}

The author declares that there is no conflict of interest.

\section{References}

[1] Li B, 2019, Rational Discussion on Some Problems of Sponge City Construction. Real Estate Guide, 2019(24): 5.

[2] Luo Q, 2021, Research Progress and Discussion on Some Problems of Sponge City Construction in Mountain Areas. Architecture and Decoration, 2021(1): 136, 140.

[3] Sun Z, 2018, Analysis on Some Problems in Drainage and Waterlogging Prevention and Construction of Sponge City. Construction Science and Technology, 2018(1): 19-20.

[4] Tang H, Bai X, 2019, Research Progress and Discussion on Some Problems of Sponge City Construction. Urbanism and Architecture, 16(5): 159-160.

[5] Han Y, 2019, Analysis of Hydrology Problems in Sponge City Construction. Science \& Technology Vision, 2019(2): 6-7.

[6] Yang Z, 2018, Research Progress and Discussion on Some Problems of Sponge City Construction. Architecture and Decoration, 2018(10): 127, 130.

[7] Li L, Zhang S, 2018, Research Progress and Discussion on Some Problems of Sponge City Construction. Architecture Engineering Technology and Design, 2018(14): 92.

[8] An H, An J, 2016, Research Progress and Discussion on Some Problems of Sponge City Construction. Architecture Engineering Technology and Design, 2016(28): 1861.

[9] Zhang Y, 2016, Exploration and Analysis on Some Problems of Sponge City Construction. Architecture Engineering Technology and Design, 2016(19): 3645.

[10] Du X, Han Q, Yu Z, et al., 2017, Analysis on Some Problems in the Application of Biological Retention Facilities in Sponge City Construction. Water \& Wastewater Engineering, 43(1): 54-58. 